\title{
Sıçanlarda Akrilonitril ile Oluşturulmuş Oksidatif Strese Karşı Timokinon ve Kurkuminin Olası Koruyucu Etkileri ${ }^{*}$
}

Possible Protective Effects of Thymoquınone and Curcumin on acrylonitrile-induced oxidative stress in

Rats

\author{
Kemal Akkayai, Metin Yıldııımii, Ulaş Değirmenciii, Nil Doğruer Ünaliv \\ iDoktora Öğr., Mersin Üniversitesi, Eczacılık Fakültesi, Biyokimya AD., https://orcid.org/0000-0001-7459-4612 \\ iiDr.Öğr. Üyesi, Tarsus Üniversitesi, Sağlık Hizmetleri Meslek Yüksekokulu, Eczane Hizmetleri Bölümü, \\ https://orcid.org/0000-0003-1346-312X \\ iiiDr.Öğr. Üyesi Harran Üniversitesi, Eczacılık Fakültesi, Biyokimya AD., https://orcid.org/0000-0001-5208-6430 \\ ivDr.Öğr. Üyesi Mersin Üniversitesi, Eczacılık Fakültesi, Biyokimya AD., https://orcid.org/0000-0002-4083-0944
}

öz

Giriş: Akrilonitril, akrilik elyaf, reçine ve plastikler gibi çeşitli organik ürünlerin sentezinde, yaygın olarak kullanılmaktadır. Akrilonitril maruziyeti oksidatif strese neden olmaktadır. Timokinon ve kurkumin antioksidan, anti-inflamatuar ve antikanser özelliklere sahiptir.

Amaç: Bu çalışmada, akrilonitril ile oluşturulmuş oksidatif strese karşı kurkumin ve timokinonun olası koruyucu etkileri incelendi.

Yöntem: Çalışmaya dahil edilen 42 sıçan her grupta 7 sıçan olacak şekilde 6 gruba ayrıldı. 21 gün boyunca akrilonitril, kurkumin ve timokinon uygulaması gerçekleştirildi. Çalışmanın sonunda hayvanlar sakrifiye edilerek izole edilen karaciğer ve böbrek dokularında süperoksit dismutaz (SOD) ve katalaz (CAT) enzimlerinin aktiviteleri ile malondialdehit (MDA) ve glutatyon (GSH) düzeyleri ölçüldü.

Bulgular: Akrilonitril uygulaması karaciğer ve böbrek dokusunda SOD, CAT aktivitelerini ve GSH seviyesini anlamlı düzeyde azaltırken MDA seviyesini arttırdığı bulunmuştur. Kurkumin ve timokinon uygulaması MDA seviyesini azaltırken SOD, CAT ve GSH seviyesini arttırmıştır.

Sonuç: Bu çalışmanın sayesinde akrilonitrilin neden olduğu oksidatif strese karşı kurkumin ve timokinonun tedavi olarak bir opsiyon olabileceği düşünülmektedir.

Anahtar kelimeler: Oksidatif stres, Akrilonitril, Kurkumin, Timokinon, Antioksidan Sistem

\section{ABSTRACT}

Introduction: Acrylonitrile is widely used in the synthesis of various organic products such as acrylic fibers, resins and plastics. Acrylonitrile exposure causes oxidative stress. Thymoquinone and curcumin have antioxidant, anti-inflammatory and anticancer properties.

Aim: In this study, possible protective effects of curcumin and thymoquinone on oxidative stress produced by acrylonitrile were investigated.

Methods: 42 rats included in the study were divided into 6 groups, with 7 rats in each group. Acrylonitrile, curcumin and thymoquinone were applied for 21 days. At the end of the study, the activities of superoxide dismutase (SOD) and catalase (CAT) enzymes and malondialdehyde (MDA) and glutathione (GSH) levels were measured in isolated liver and kidney tissues.

Results: It was found that acrylonitrile administration significantly decreased SOD, CAT activities and GSH levels in liver and kidney tissue, while increased MDA levels. Curcumin and thymoquinone administration decreased MDA levels while increased SOD, CAT and GSH levels. Conclusion: Thanks to this study, it is thought that curcumin and thymoquinone may be an option as a treatment against oxidative stress caused by acrylonitrile.

Keywords: Oxidative stress, Acrylonitrile, Curcumin, Thymoquinone, Antioxidant system

*Mersin Üniversitesi Tıp Fakültesi Lokman Hekim Tıp Tarihi ve Folklorik Tıp Dergisi, 2021; 11 (3): 596-604

DOI: $10.31020 /$ mutftd.983740

e-ISSN: 1309-8004, ISSN 1309-761X

Geliş Tarihi - Received: 17 Ağustos 2021; Kabul Tarihi - Accepted: 31 Ağustos 2021

Iletişim - Correspondence Author: Nil Doğruer Ünal <nildogruer@mersin.edu.tr>

Etik Kurul Onayı: Mersin Üniversitesi Rektörlüğü Hayvan Deneyleri Yerel Etik Kurulu (25.12.2017 tarih, 2017/28 no) 


\section{Giriş}

Günümüzde endüstriyel üretimde kullanılan kimyasalların, doğal ortama salınması canlıların yaşamlarını sağlıklı bir şekilde sürdürebilmesini tehlikeye düşürebilmektedir. Bu kimyasallar, çevresel kirleticiler olarak adlandırımaktadır. ${ }^{1}$ Çevresel kirleticilerden biri olan Akrilonitril, akrilik elyaf, reçine ve plastikler gibi çeşitli organik ürünlerin sentezinde, yaygın olarak kullanılmaktadır. ${ }^{2}$

Emilimi yüksek olan akrilonitrilin, temas ettiği dokularda tahrişe neden olduğu bilinmektedir. Akrilonitril maruziyeti sonrası, lokal toksisite yanı sıra sistemik toksisite de görülebilir. Akrilonitrilin inhale edilmesi, içme suyuna karışması, cilt teması ve mesleki maruziyeti reaktif oksijen türlerinin (ROS) artışına sebep olmaktadır. Oksidatif stres, antioksidan savunma ve oksidanlar arasındaki kritik dengenin oksidanların yönünde bozulmasıdır. ${ }^{3}$ Çok hücreli organizmalar yaşlanmaya bağlı olarak biyolojik fonksiyonlarının dejenerasyonu, hastalıklara yatkınlıkta artma ve belirli bir süre içinde ölme gibi niteliksel değişikliklere uğrarlar. Yaşlanma ile ilgili yaygın olarak kabul gören serbest radikal teorisi, yaşa bağlı dejeneratif sürecin büyük ölçüde serbest radikal hasarının sonucu ilerlediğini söyler. Ayrıca hücrede çeşitli reaksiyonlar sonucunda oluşan reaktif oksijen türleri (ROS) ve serbest radikaller DNA, protein, karbonhidrat ve lipitler gibi makromoleküllerle reaksiyona girerek yapılarını bozmaktadırlar. ${ }^{4}$ Bu hasarlar kardiyovasküler hastalıklar, renal fonksiyon bozuklukları, nörolojik hastalıklar, kanser, kas ve karaciğer hastalıkları gibi birçok patolojik durumun ortaya çıkmasına sebebiyet verebilmektedir. ${ }^{5}$ Oksidatif stres bir hastalık değildir fakat birçok hastalığa yol açabilecek ya da hastalığı hızlandırabilecek bir etkendir. Oksidatif stresi tehlikeli kılan durum herhangi bir semptomunun olmamasıdır. $^{6}$

Oksidatif stres kaynaklı olumsuz etkilerin azaltılması veya yok edilmesi amacıyla folklorik tıpta sıkça kullanılan bitki ekstraktları ve bu ekstraktlarda mevcut olan etkin maddeler üzerine yapılan çalışmaların sayısı gün geçtikte artış göstermektedir. Asya'nın tropikal bölgelerinde yaygın olarak yetiştirilen, Zingiberaceae ailesi üyesi, çok yıllık bir bitki olan Curcuma longa (zerdeçal) bitkisinin rizomlarında bol miktarda bulunan doğal bir polifenolik bileşik olan Kurkumin'in antik zamanlardan bu yana folklorik tıpta topikal veya oral uygulamaları mevcuttur. Ayrıca bu etkin madde anti-inflamatuar ve antikanser özelliklere sahiptir. Pakistan, Hindistan ve Bangladeş'te geleneksel olarak kozmetik uygulamaları bilinmektedir. Hindistanın kuzeyinde dağlık bölgede yaşayan insanlar derilerini güneşten korumak için kurkumin kullanmaktadır . ${ }^{7}$ Siyah kimyon olarak da bilinen Nigella sativa L., Ranunculaceae ailesinin bir üyesidir ve Akdeniz bölgesindeki ülkelere özgüdür. ${ }^{8}$ Timokinon, Nigella sativa uçucu yağının (\%54) biyoaktif bileşenidir. Antiinflamatuar, antioksidan ve antineoplastik etkilerin hem in vitro hem de in vivo uygulamada oluştuğu gösterilmiştir. ${ }^{9}$ Arap ve yunan folklorik tıbbında kadın hastalıklarında yaygın olarak kullanılmışır. Buna ek olarak Hindistan'da süt arttırıcı olarak kullanılmaktadır. ${ }^{10} \mathrm{Bu}$ çalışma ile, akrilonitrilin karaciğer ve böbrek dokusunda oluşturduğu oksidatif strese karşı, kurkumin ve timokinonun olası koruyucu özelliklerinin incelenmesi amaçlanmıştır.

\section{Gereç ve Yöntem}

\section{Kimyasallar}

Çalışmamızda, kurkumin (Sigma), timokinon (Sigma), akrilonitril (Aldrich), tiobarbitürik asit (TBA) (Merck), ksantin (Sigma), ksantin oksidaz (Sigma), trikloroasetik asit (TCA) (Merck), ketamin (Pfizer), ksalazin (Bayer), sodyum klorür (Merck), 1-butanol (Riedel de Haen), amonyum sülfat (Sigma), asetik asit (Merck), bakır klorür (Sigma), bakır sülfat pentahidrat (Merck), bovine serum albumin (BSA) (Sigma), disodyum hidrojen fosfat (Merck), etil alkol (etanol) (Merck), etilendiamintetraasetikasit (EDTA) (Merck), folin ciocalteu's fenol reagent (Sigma), glutatyon redüktaz (Sigma), $\mathrm{H}_{2} \mathrm{O}_{2}$ (Merck), ksalazin (Bayer), ksantin oksidaz (Sigma), nitroblue tetrazolium klorür (NBT) (Sigma), piridin (Riedel de Haen), potasyum dihidrojen fosfat (Merck), potasyum sodyum tartarat (Merck), redükte L-glutatyon (Sigma), redükte $\beta$-NADPH (Sigma), sodyum azid (Sigma), 
sodyum dodesil sülfat (Sigma), sodyum hidroksit (Merck), sodyum karbonat (Merck), tetrametoksipropan (Aldrich) kullanıldı.

\section{Yöntem}

Bu çalışmada, Mersin Üniversitesi (MEÜ) Tıp Fakültesi Deneysel Tıp Araştırma Merkezinden temin edilen ağırlıkları 250-350 gr arasında değişen, 42 adet, erişkin erkek Wistar Albino sıçan kullanıldı. Her grupta eşit sayıda olacak şekilde 6 gruba ayrılan sıçanlar, MEÜ Tıp Fakültesi Deney Hayvanları Araştırma Laboratuvarında Euro standart tip IV kafeslerde ve her grup ayrı kafeste yer alacak şekilde muhafaza edilerek, standart sıçan yemi ve su ile ad libitum beslendi. Sıçanlar 12 saat ışık/karanlık periyodunda ve $18-22^{\circ} \mathrm{C}^{\prime}$ de ortam sıcaklığında muhafaza edildi. Tüm gruplar eş zamanlı olarak çalışıldı. Çalışma için MEÜ Hayvan Deneyleri Yerel Etik kurulundan (Kurulun 08/01/2018 tarihli ve 01 sayılı kararı) onay alındı ve tüm çalışmalar Etik Kurul ilkelerine uygun olarak gerçekleştirildi.

\section{Çalışma grupları:}

Kontrol grubundaki (Grup I) sıçanlara 21 gün boyunca $1 \mathrm{ml} \% 0.9$ serum fizyolojik (SF) gavaj yoluyla verildi. Akrilonitril grubundaki (Grup II) sıçanlara 21 gün boyunca $50 \mathrm{mg} / \mathrm{kg}$ akrilonitril gavaj yoluyla verildi. Kurkumin grubundaki (Grup III) sıçanlara 21 gün boyunca 100 mg/kg kurkumin gavaj yoluyla verildi. Akrilonitril + Kurkumin grubundaki (Grup IV) sıçanlara 21 gün boyunca 50 mg/kg akrilonitril ve 100 mg/kg kurkumin gavaj yoluyla verildi.

Timokinon grubundaki (Grup V) sıçanlara 21 gün boyunca $15 \mathrm{mg} / \mathrm{kg}$ Timokinon gavaj yoluyla verildi.

Akrilonitril + Timokinon grubundaki (Grup VI) sıçanlara 21 gün boyunca $50 \mathrm{mg} / \mathrm{kg}$ akrilonitril ve $15 \mathrm{mg} / \mathrm{kg}$ timokinon gavaj yoluyla verildi.

Çalışmanın 22. gününde sıçanlar ketamin anestezisi altında sakrifiye edilip, karaciğer ve böbrek dokuları izole edildi.

\section{Dokuların Hazırlanması}

İzole edilen karaciğer ve böbrek dokuları yaş ağırlıkları $100 \mathrm{mg}$ olarak porsiyonlandı ve $0.1 \mathrm{M}$ fosfat tamponu (pH:7.4) ile homojenize edildi. Doku homojenatları $13000 \mathrm{rpm}^{\prime}$ de $+4^{\circ} \mathrm{C}^{\prime}$ de 10 dakika süre ile santrifüj edildi. Süpernatantlar, protein, MDA, GSH düzeyleri ile SOD ve CAT enzim aktivitelerini belirlemek amacıyla ayrıldı.

\section{Biyokimyasal Analizler}

Protein ölçümü Lowry metoduna göre yapıldı. Metoda göre proteinler alkali çözelti içinde Cu iyonu ile ön muameleye tabi tutulur ve daha sonra işlenmiş numunedeki aromatik amino asitler Folin Reaktifi'nde bulunan fosfomolibdik fosfotungustik asit'i mavi renkli son ürüne indirger oluşan renklenmenin şiddeti ile protein miktarı koreledir. ${ }^{11}$

SOD enzim aktivitesinin ölçümü, oksidatif yoldan enerji üretilirken oluşturulan toksik süperoksit radikalinin $\left(\mathrm{O}_{2} \cdot{ }^{-}\right) \mathrm{H}_{2} \mathrm{O}_{2}$ 'e ve moleküler oksijene $\left(\mathrm{O}_{2}\right)$ dismutasyonunu hızlandırarak etki gösteren SOD'nin enzim aktivite tayini, ksantin varlığında XOD kullanılarak oluşturulan süperoksit radikallerinin nitroblue tetrazolium (NBT) ile oluşturduğu mavi renkli formazan boyasının $560 \mathrm{~nm}$ dalga boyunda absorblanan renginin ölçülmesiyle elde edilen optik dansitenin okunması esasına dayanmaktadır. ${ }^{12}$

MDA ölçümü, lipit peroksit ayrışmasının son ürünü olan renksiz MDA'nın aerobik şartlarda ve pH 3,4'de tiyobarbitürik asit ile $95{ }^{\circ} \mathrm{C}^{\prime}$ de inkübasyonu sonucu pembe-kırmızı renkli bir bileşik oluşması ve oluşan bileşiğin $532 \mathrm{~nm}$ dalga boyunda ölçülmesi esasına dayanmaktadır. ${ }^{13}$ 
GSH ölçümü prensibi, sülfidril gruplarının spektrofotometrik ölçümlerine dayanmaktadır. 5,5'-ditiyobis (2nitrobenzoik asit) (DTNB)'nin GSH'nin sülfidril grupları ile tepkimesiyle bir mol-SH grubuna karşılık bir mol 2nitro-5-merkaptobenzoik asit vererek DTNB indirgenir ve nitrobenzoik asitle birlikte meydana gelen güçlü sarı rengin şiddeti spektrofotometre ile 412 nanometre $(\mathrm{nm})$ dalga boyunda ölçülür. ${ }^{14}$

CAT enzim aktivitesinin ölçümü, katalaz enzimi tarafından $\mathrm{H}_{2} \mathrm{O}_{2}$ 'in su ve moleküler $\mathrm{O}_{2}$ 'ye ayrıştırılma hızı, $\mathrm{H}_{2} \mathrm{O}_{2}{ }^{\prime}$ in $240 \mathrm{~nm}$ dalga boyunda ışığı absorbe etmesinden yararlanılarak spektrofotometrik olarak izlenmesi esasına dayanmaktadır. ${ }^{15}$

\section{İstatistiksel Analiz}

Çalışma sonucunda elde edilen verilerin değerlendirilmesinde "SPSS 20.0 for Windows (Free trailer)" paket programı ile "One Way Anova-Tukey" testi kullanıldı. Tüm istatistik uygulamalar sonucunda sayısal değer (p) olarak ortaya çıkan deney grupları arasındaki farklar, $p<0,05$ önem derecesinde anlamlı olarak kabul edildi.

\section{Bulgular}

Hem Karaciğer ve hem de böbrek dokusunda Grup II ile Grup I karşıllaştırıldığında, Grup II'de SOD, CAT aktivitelerinin ve GSH düzeyinin istatistiksel olarak anlamlı şekilde azaldığı bulunmuştur $(p<0,05)$. Grup III ile Grup II karşılaştırıldığında, Grup III'de SOD, CAT aktiviteleri ve GSH düzeyinin istatistiksel olarak anlamlı düzeyde arttığı bulunmuştur $(p<0,05)$. Grup V ile Grup II karşılaştırıldığında, Grup V'de SOD, CAT aktivitelerinin ve GSH düzeyinin arttığı ve bu değişikliğin istatistiksel olarak anlamlı olduğu belirlenmiştir $(p<0,05)$. Grup IV ile Grup III karşılaştırıldığında, Grup IV'de SOD, CAT aktivitelerinin ve GSH düzeyinin istatistiksel olarak anlamlı şekilde arttığı bulunmuştur $(p<0,05)$. Grup VI ile Grup V karşılaştırıldığında, Grup VI'da SOD, CAT aktivitelerinin ve GSH düzeyinin istatistiksel olarak anlamlı şekilde arttığı bulunmuştur $(p<0,05)$ (Şekil 2-8).

Grup II ile Grup I karşılaştıııldığında, Grup II'de MDA düzeyinin anlamlı şekilde arttığı belirlenmiştir $(p<0,05)$. Grup III ile Grup II karşılaştırıldığında, Grup III'de MDA düzeyinin azaldığı ve bu değişikliğin istatistiksel olarak anlamlı olduğu görülmüştür $(p<0,05)$. Grup V ile Grup II karşılaştıııldığında, Grup V'de MDA düzeyinin istatistiksel olarak anlamlı düzeyde azaldığı belirlenmiştir $(p<0,05)$. Grup IV ile Grup III karşılaştırıldığında, Grup IV'de MDA düzeyinin istatistiksel olarak anlamlı şekilde azaldığı bulunmuştur $(p<0,05)$. Grup VI ile Grup V karşılaştırıldığında, Grup VI'da MDA düzeyinin istatistiksel olarak anlamlı şekilde azaldığı bulunmuştur $(\mathrm{p}<0,05)$ (Şekil 1,5).

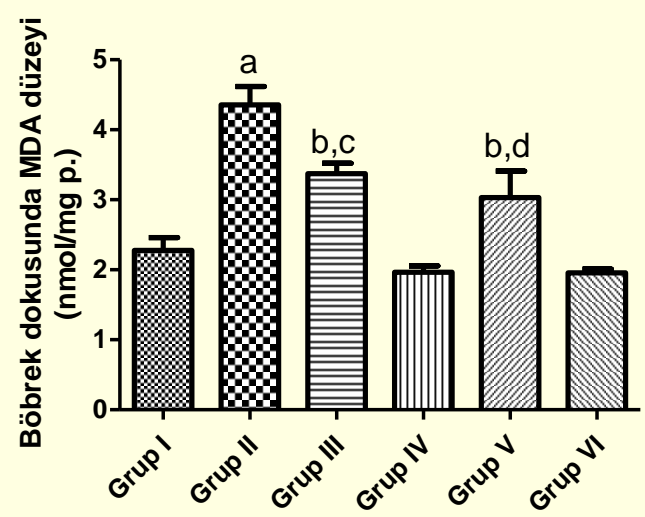

Şekil 1. Böbrek dokusunda MDA düzeyi a Grup I ile kıyaslandığında anlamlı fark $p<0,05$ b Grup II ile kıyaslandığında anlamlı fark $p<0,05$ c Grup IV ile kıyaslandığında anlamlı fark $p<0,05$ d Grup VI ile kıyaslandığında anlamlı fark $p<0,05$

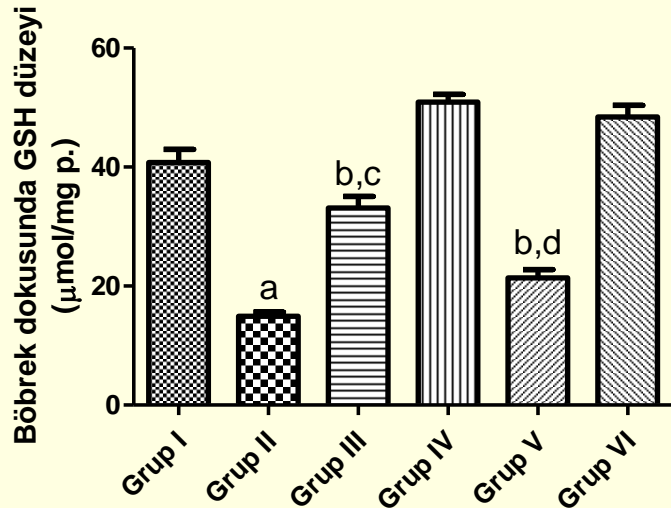

Şekil 2. Böbrek dokusunda GSH düzeyi

${ }^{a}$ Grup I ile kıyaslandığında anlamlı fark $p<0,05$

b Grup II ile kıyaslandığında anlamlı fark $p<0,05$

c Grup IV ile kıyaslandığında anlamlı fark $p<0,05$

d Grup VI ile kıyaslandığında anlamlı fark $p<0,05$ 


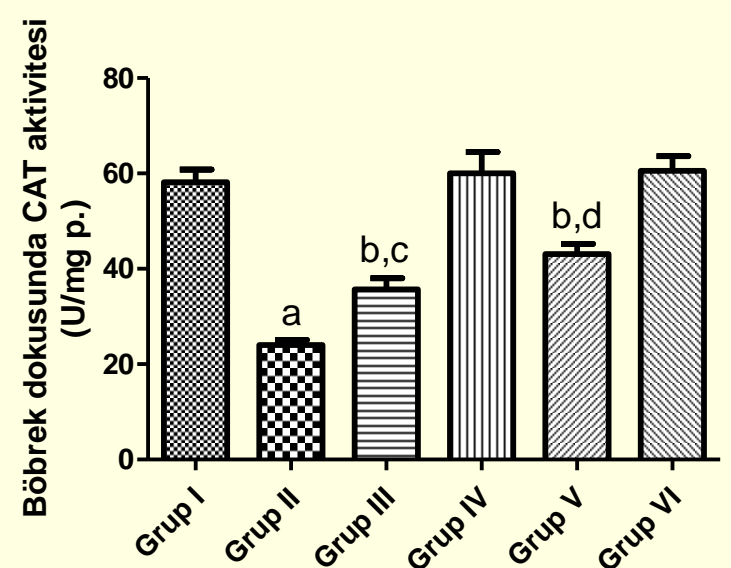

Şekil 3. Böbrek dokusunda CAT aktivitesi

a Grup I ile kıyaslandığında anlamlı fark $p<0,05$

b Grup II ile kıyaslandığında anlamlı fark $p<0,05$

c Grup IV ile kıyaslandığında anlamlı fark $p<0,05$

d Grup VI ile kıyaslandığında anlamlı fark $p<0,05$

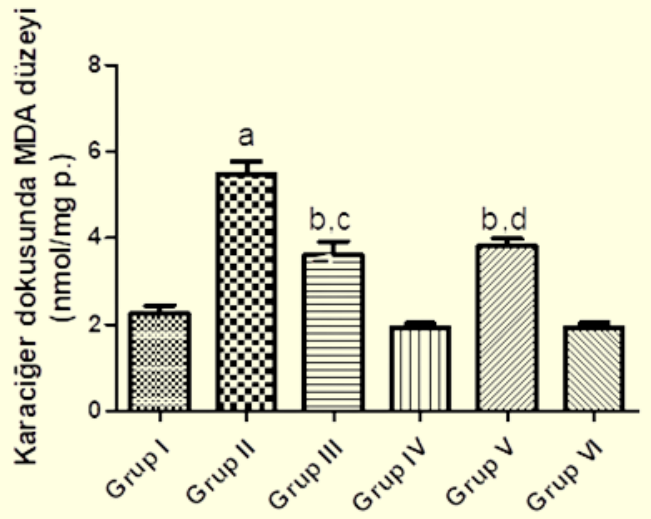

Şekil 5. Karaciğer dokusunda MDA düzeyi

a Grup I ile kıyaslandığında anlamlı fark $p<0,05$

b Grup II ile kıyaslandığında anlamlı fark $p<0,05$

c Grup IV ile kıyaslandığında anlamlı fark $p<0,05$

d Grup VI ile kıyaslandığında anlamlı fark $p<0,05$

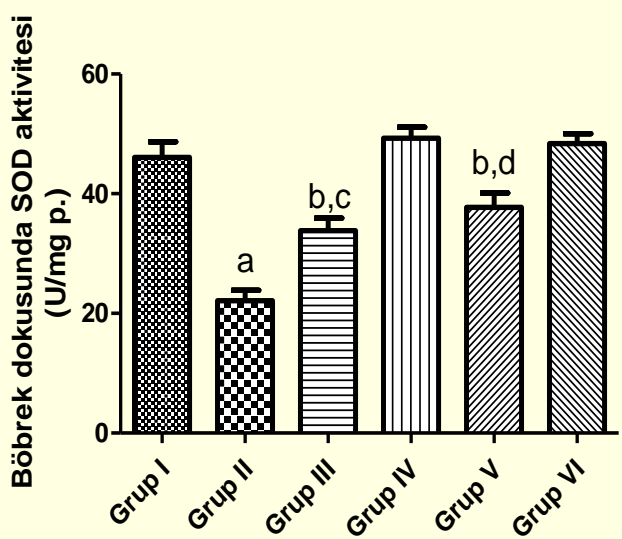

Şekil 4. Böbrek dokusunda SOD aktivitesi

a Grup I ile kıyaslandığında anlamlı fark $p<0,05$

b Grup II ile kıyaslandığında anlamlı fark $p<0,05$

c Grup IV ile kıyaslandığında anlamlı fark $p<0,05$

d Grup VI ile kıyaslandığında anlamlı fark $p<0,05$

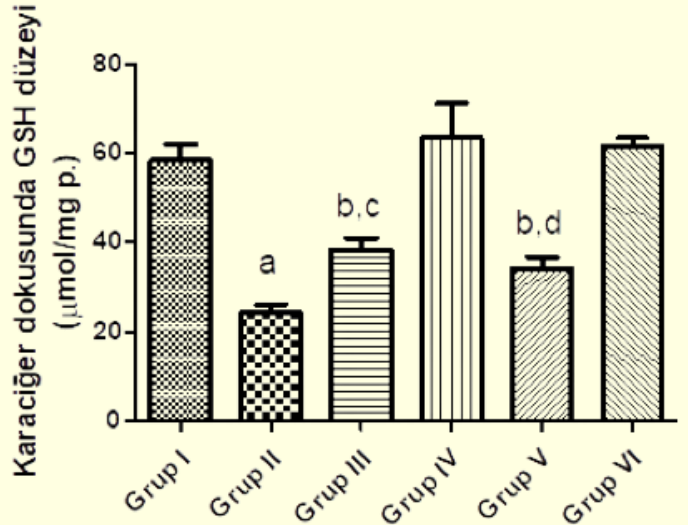

Şekil 6. Karaciğer dokusunda GSH düzeyi

a Grup I ile kıyaslandığında anlamlı fark $p<0,05$

b Grup II ile kıyaslandığında anlamlı fark $p<0,05$

c Grup IV ile kıyaslandığında anlamlı fark $p<0,05$

d Grup VI ile kıyaslandığında anlamlı fark $p<0,05$ 

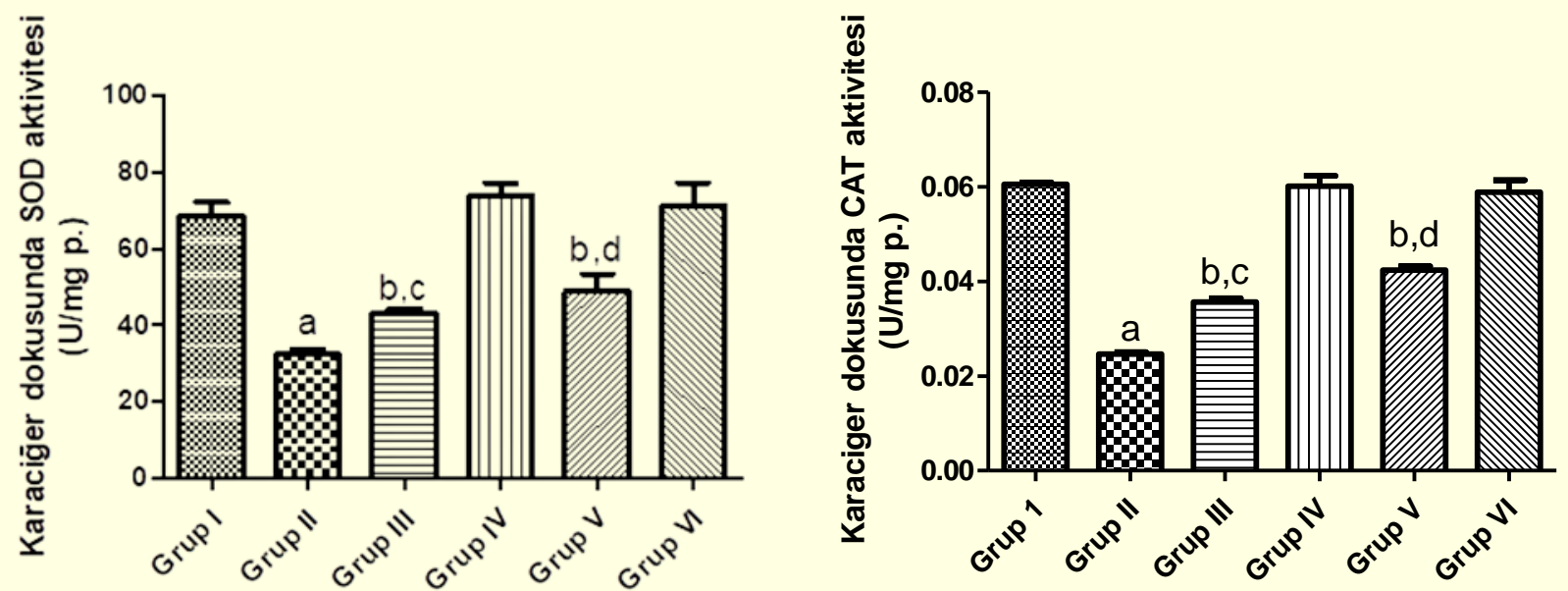

Şekil 7. Karaciğer dokusunda SOD aktivitesi

a Grup I ile kıyaslandığında anlamlı fark $p<0,05$

b Grup II ile kıyaslandığında anlamlı fark $p<0,05$

c Grup IV ile kıyaslandığında anlamlı fark $p<0,05$

d Grup VI ile kıyaslandığında anlamlı fark $p<0,05$

Şekil 8. Karaciğer dokusunda CAT aktivitesi

${ }^{a}$ Grup I ile kıyaslandığında anlamlı fark $p<0,05$

b Grup II ile kıyaslandığında anlamlı fark $p<0,05$

c Grup IV ile kıyaslandığında anlamlı fark $p<0,05$

d Grup VI ile kıyaslandığında anlamlı fark $p<0,05$

\section{Tartışma}

Oksijen $\left(\mathrm{O}_{2}\right)$ aerobik canlıların yaşamı için vazgeçilmez bir moleküldür. Mitokondride $\mathrm{O}_{2}$ kullanılarak üretilen Adenozin trifosfat (ATP) ile beraber serbest radikaller de oluşmaktadır. Serbest radikaller redoks reaksiyonu sonucu ortaya çıkan reaktif azot türleri (RNS) ve reaktif oksijen türleri (ROS)'dir. Bu türler çeşitli biyomoleküller için zararlı etkiler gösterebilmesinin yanında canlının savunma sistemlerinde kullanılması gibi yararlı da olabilmektedir. Serbest radikallerin zıt etkileri arasındaki hassas denge yaşamı açıkça etkileyen önemli bir etmendir. ${ }^{14}$ Oksidatif stres, hücrelerde hidroksil radikali $\left(\mathrm{OH}_{-}\right)$, süperoksit radikali $\left(\mathrm{O}^{2}\right)$ ve $\mathrm{H}_{2} \mathrm{O}_{2}$ gibi ROS'un miktarının artması veya bunları zararsız hale getiren antioksidanların azalması sonucu oksidatif dengenin bozulması durumudur. ${ }^{17}$ Son yıllarda yapılan çalışmalarda, oksidatif stresin pek çok hastalığın patogenezinde etken olarak gösterilmesi dikkat çekmektedir. Oksidatif stres kaynaklı olumsuz etkilerin azaltılması veya yok edilmesi amacıyla farklı yollar araştıran çalışmaların sayısı gün geçtikte artış göstermektedir. ${ }^{18}$ Oksidatif stresin ortaya çıkması çeşitli faktörler sonucu olabilmektedir. Çevresel kirleticiler de bu sebeplerden biridir. Nitril kauçuk, polimerize edilmiş plastikler ve atılabilir şişeler gibi günlük hayatta da sıklıkla karşımıza çıkan ürünlerin üretiminde de yaygın olarak kullanılan reaktif bir kimyasal olan akrilonitril, ABD Environmental Protection Agency (EPA)'ye göre tehlikeli bir su ve hava kirleticisidir. ${ }^{19}$ Akrilonitrilin değişen dozları çeşitli canlılar üzerinde toksik etki göstermektedir. ${ }^{18}$ Birçok çalışmada oksidatif stresin akrilonitril toksisitesindeki rolü gösterilmiştir. ${ }^{21}$ Akrilonitrilin ana eliminasyon yolu Glutatyon S-transferaz (GST) enziminin katalizlediği reaksiyonla merkapturik asit oluşturmak için GSH ile konjugasyonu ve sitokrom P450 ile siyanür (CN) üretimidir. ${ }^{22}$

Sıçanlarla yapılan deneyler, karaciğer, akciğer, böbrek ve adrenalde indirgenmiş GSH'da doza bağlı hızlı bir azalmayı göstermektedir. Serebral GSH konsantrasyonunun azalması aşamalıdır ve akut deneylerde mortalite oluşumu ile korelasyon göstermektedir. İçme suyundaki akrilonitrilin kronik olarak alınması, kimyasal karsinojenlerin neden olduğu gibi hepatik GSH konsantrasyonunun doza bağlı olarak artmasına neden olur. ${ }^{23}$ Guangwei ve ark. sıçanlarla yaptıkları yedi günlük çalışmada gavaj yoluyla verilen akrilonitrilin kontrol grubuna göre beyin ve karaciğerdeki SOD ve CAT aktivitesi ile GSH seviyesini düşürdüğünü, MDA seviyesini ise arttırdığını ancak SOD aktivitesindeki azalmanın anlamlı olmadığını bildirmiştir. Aynı çalışmada akrilonitril ile birlikte kurkumin verilen grupta yalnızca akrilonitril verilen gruba göre beyin ve karaciğerdeki SOD ve CAT aktivitesi ile GSH seviyesinin arttığı MDA seviyesinin ise azaldığı bildirilmiştir. ${ }^{24}$ Bizim çalışmamızda da 
Guangwei ve ark.'nın yaptığı çalışmanın sonuçları ile benzer şekilde akrilonitrilin hepatotoksik etkileri ve kurkuminin bu toksisiteyi tedavi edici etkileri görüldü. Bu çalışmadan farklı olarak SOD aktivitesinin bizim çalışmamızda anlamlı azalışı akrilonitrile maruziyet süresinin toksisiteyi artırdığını göstermektedir. Abo salem ve ark.'nın yaptıkları çalışmada akrilonitril verilen sıçanlarda hepatik MDA içeriğinin anlamlı şekilde arttığı, GSH, SOD ve GSH-Px'in hepatik aktivitesinin sırasıyla \%72.4, \%81 ve \%53.2 oranında azaldığı gösterilmiştir. ${ }^{25}$ Benzer bulgular Mahalakshmi ve ark. tarafından da rapor edilmiştir. ${ }^{26}$ Bizim çalışmamızda da bu çalışmalara paralel şekilde akrilonitrilin oksidatif stres kaynaklı hepatotoksik etkileri ve kurkuminin antioksidan özellikleri sayesinde bu toksisiteyi tedavi edici etkileri görüldü. Yayla ve ark.'nın Nigella sativa L. etanol ekstresi kullanarak karaciğer dokusu üzerinde yaptıkları çalışmada kontrol grubu ile gavaj olarak $1000 \mathrm{mg} / \mathrm{kg}$ Nigella sativa L. etanol ekstresi verilen grup arasında sıçan serumunda ölçülen SOD aktivitesi, MDA ve GSH seviyelerinde belirgin bir değişim gözlenmediğini bildirmişlerdir. ${ }^{27}$ Bizim çalışmamızda ise bu çalışmadan farklı olarak timokinon verilen grupta kontrol grubuna göre SOD aktivitesi ve GSH seviyelerinde artış, MDA düzeyinde ise azalma gözlendi. Bulgularımıza göre timokinonun, Nigella sativa L. etanol ekstresinden daha etkili bir antioksidan olduğu söylenebilir. Sayed-Ahmed ve ark. sıçanlarda gentamisinle oluşturdukları akut renal toksisitede kan CAT aktivitesinin ve GSH düzeyinin kayda değer şekilde azaldığını, timokinon verilen sıçanlarda ise önemli miktarda arttı̆̆ını bildirmişlerdir. ${ }^{28}$ Meguid ve ark. diyabet sonucunda dokularda MDA düzeyinin yükseldiğini, serum SOD aktivitesinin azaldığını, buna karşın timokinonun haftada altı gün olmak üzere 30 gün boyunca verilmesiyle birlikte MDA seviyesinin artışının azaldığını, doku SOD aktivitesinin ise arttığını bildirmişlerdir. ${ }^{29}$ Bizim çalışmamızda da bu çalışmalara benzer şekilde timokinonun oksidatif stres oluşturucu etkenlerin düşürdüğü SOD ve CAT aktivitesi ile GSH düzeyini artırdığı aynı zamanda lipit peroksidasyonun yıkım ürünlerinden olan ve oksidatif stres sonucu yükselen MDA düzeyini de azalttığı gözlendi.

Literatüre baktığımızda çalışmamızda kullanılan kurkumin ve timokinonun benzer dozlarının diğer çalışmalarla uyumlu görülmemesinin sebebinin etkin madde uygulama süresinin kısalığına bağlı olduğu düşünülmektedir. Akrilonitril verilmesinden sonra literatürle uyumlu olacak şekilde sıçanlarda ağırlık kaybı ve hareketlerde yavaşlama ile birlikte akrilonitrilin karaciğer ve böbrek dokularında SOD, CAT aktivitelerinde ve GSH, MDA düzeylerinde yaptığı değişikliklere bakarak oksidatif stres yarattığını ayrıca doğal bileşikler olan kurkumin ve timokinonun antioksidan sistem üzerine olumlu ve oksidatif hasarı tedavi edici etkileri gözlemlendi.

Dünyada ve ülkemizde yaygın kullanıma sahip olan folkolorik tıp bitkileri Nigella sativa L. ve Curcuma longa iyileştirici etkilere sahiptir. İbni sina, Nigella sativa L. bitkisinin akciğeri güçlendirdiğini metabolizmayı hızlandırdığını ve yara tedavisinde kullanılabileceğini "Kanun" adlı eserinde belirtmiştir. ${ }^{10} \mathrm{Bu}$ bitkilerden elde edilen ekstrakt ve yağlar folklorik tıpta oldukça önemli bir yere sahiptir. Bu bitkilerin etkin maddeleri olan timokinon ve kurkumin son yıllarda antikanser, anti-inflamatuvar ve antioksidan çalışmaları günden güne artmaktadır. Çalışmamız sayesinde elde edilen bilimsel veriler folklorik tıpta kullanılan bu bitkilerin tedavi edici özelliği desteklemektedir.

Sonuç olarak, hâlihazırdaki bulgular sanayide oldukça yaygın kullanılan ve bir çevresel kirletici olan akrilonitrilin toksik etkilere sahip olduğunu ve bu etkilerin oksidatif stresin oluşmasında etkili olabileceğini ortaya koymuştur. Bununla birlikte, kurkumin ve timokinon güçlü antioksidan etkileri nedeniyle akrilonitril gibi çevresel kirleticelere maruziyet sonucu oluşan oksidatif stresin neden olduğu doku ve organ hasarında tedavi edici olabilirler. Çalışmamızdan elde edilen verilerin ışığında akrilonitril gibi oksidatif stres oluşturucu toksik kaynakların etkilerinden korunmak için gerek kurkumin ve gerekse de timokinon birer alternatif olabilirler. Bir çevresel kirletici olan akrilonitrilin toksik etkileri nedeniyle mümkünse hiç kullanılmaması 
gerektiği, kullanımdan kaldırılamıyorsa buna maruz kalan bireylere proflaksi amaçlı kurkumin veya timokinon kullanımı önerilebilir.

\section{Bilgi}

Çıkar çatışması bulunmamaktadır.

Bu çalışma Kemal Akkaya'nın Mersin Üniversitesi, Sağlık Bilimleri Enstitüsü, Eczacılık Biyokimya Anabilim Dalı'nda yapılan "Sıçanlarda Akrilonitril ile Oluşturulmuş Oksidatif Strese Karşı Timokinon ve Kurkuminin Olası Koruyucu Etkilerinin Araştırılması" başlıklı Yüksek Lisans Tezinden üretilmiştir.

\section{Etik Onay}

Mersin Üniversitesi Rektörlüğü Hayvan Deneyleri Yerel Etik Kurulu'ndan onay alınmıştır (25.12.2017 tarih, 2017/28 no).

\section{Araştırmacı Katkı Oranı Beyanı}

Kemal Akkaya: Fikir/kavram, tasarım, denetleme/danışmanlık, veri toplama veya işleme, analiz veya yorum, kaynak taraması, makalenin yazımı, eleştirel inceleme.

Metin Yıldırım: Fikir/kavram, tasarım, denetleme/danışmanlık, veri toplama veya işleme, analiz veya yorum, kaynak taraması, makalenin yazımı, eleştirel inceleme.

Ulaş Değirmenci: Fikir/kavram, tasarım, denetleme/danışmanlık, veri toplama veya işleme, analiz veya yorum, kaynak taraması, makalenin yazımı, eleştirel inceleme.

Nil Doğruer Ünal: Fikir/kavram, tasarım, denetleme/danışmanlık, veri toplama veya işleme, analiz veya yorum, kaynak taraması, makalenin yazımı, eleştirel inceleme.

\section{Kaynaklar}

1. World Health Organization. Acrylonitrile-Environmental Health Criteria 1983;28.

2. Güvendik G, Boşgelmez İ. Acrylonitrile. Ankara Üniversitesi Eczacılık Fakültesi Dergisi 2000;29(1):31-58.

3. Naruszewicz M. Chronic intake of potato chips in humans increases the production of reactive oxygen radicals by leukocytes and increases plasma C-reactive protein: a pilot study. The American journal of clinical nutrition 2019;89(3):773-7.

4. Koca N, Karadeniz F. Serbest radikal oluşum mekanizmaları ve vücuttaki antioksidan savunma sistemleri. Gıda Mühendisliği Dergisi 2003; 16: 32-7.

5. Freeman BA, Crapo JD. Biology of disease: free radicals and tissue injury. Lab invest 1982;47(5):412-26.

6. Gedik S. Ratlarda akrilamid kaynaklı olası oksidatif stres üzerine krosininin etkilerinin araştırılması (Yüksek Lisans Tezi), EYüP ALTINÖZ, Yayınlanmış Tez, Karabük, 2017.

7. Akbar MU, et al. Critical review on curcumin as a therapeutic agent: From traditional herbal medicine to an ideal therapeutic agent. Crit Rev Eukaryot Gene Expr 2018; 28(1): 17-24.

8. Babayan V, Koottungal D, Halaby G. Proximate analysis, fatty acid and amino acid composition of Nigella sativa L. seeds. J Food Sci 1978; 43(4):1314-5.

9. Gali-Muhtasib HU, et al. Molecular pathway for thymoquinone induced cell-cycle arrest and apoptosis in neoplastic keratinocytes. Anticancer Drugs 2004;15: 389-99.

10. Gün M. Kutsal Tohum (Nigella Sativa): Çörek Otunun İyileştirici Etkisine İlişkin Bazı Bilgiler. Mersin Üniversitesi Tıp Fakültesi Lokman Hekim Tıp Tarihi ve Folklorik Tıp Dergisi 2012; 2 (1): 43-6.

11. Lowry $\mathrm{OH}$, et al. Protein measurement with the Folin phenol reagent. J Biol Chem 1961;193:265-75.

12. Sun Y, Oberley LW, Ying L. A simple method for clinical assay of superoxide dismutase. Clin Chem 1988;34:497-500.

13. Yagi K. Simple procedure for specific enzyme of lipid hydroperoxides in serum or plasma. Methods Mol Biol $1998 ; 108: 107-110$.

14. Moron MS, Depierre JW, Mannervik B. Levels of glutathione, glutathione reductase and glutathione S-transferase activities in rat lung and liver. Biochim Biophys Acta 1979;582(1):67-78. doi:10.1016/0304-4165(79)90289-7.

15. Aebi H. Catalase in vitro. Methods Enzymol 1984;105:121-6.

16. Pham-huy LA, He H, Pham-Huy C. Free radicals, antioxidants in disease and health. International Journal of Biomedical Science 2008; 4(2): 89-96.

17. Yonar SM. Farklı Su Sıcaklıklarında Tutulan Pullu Sazan (Cyprinus carpio)'da Çörek Otu (Nigella sativa) Yağının Oksidatif Stres ve Bazı Antioksidan Parametrelere Etkisi. Türk Tarım - Gıda Bilim ve Teknoloji Dergisi 2017;5(9):1038-43. 
18. Balkan S. Eritrositlerde in vitro Oksidatif Strese Karşı Antioksidan Olarak Değerlendirilen Çeşitli Bitki Ekstraktları. Trakya University Journal of Natural Sciences 2017;18(2): 185-91.

19. Leonard A, et al. Mutagenicity, carcinogenicity, and teratogenicity of acrylonitrile. Mutat Res 1999;436,263-83.

20. Talınlı I, Sunar T, Pilatin KM. Environmental Risk Assessment of Hazardous Materials, DPT Project, i̇stanbul, 1998;14-5.

21. Recnage RO. Carbontetrachloride hepatotoxicity status quo and future prospects. Trends Pharmacol Sci 1983;4:129-30.

22. Fennell TR, Kedderis GL, Sumner Sxasdas C. Urinary metabolites of $(1,2,3-13 \mathrm{C})$ acrylonitrile in rats and mice detected by $13 \mathrm{C}$ nuclear magnetic resonance spectroscopy. Chem Res Toxicol 1991;4:678-87.

23. Szabo $S$, et al. Acrylonitrile and tissue glutahione: differential effect of acute and chronic interactions. Biochem Biophys Res Commun 1977; 79(1):32-7.

24. Guangweia $X$, et al. Curcumin pretreatment protects against acute acrylonitrile-induced oxidative damage in rats. Toxicology 2010; 267:140-6.

25. Abo-Salem OM, Abd-Ellah MF, Ghonaim MM. Hepatoprotective Activity of Quercetin againstAcrylonitrile-Induced Hepatotoxicity in Rats. Biochem Moleculer Toxicology 2011;25(6):386-92.

26. Mahalakshmi K, Pushpakiran G, Anuradha CV. Taurine prevents acrylonitrileinduced oxidative stress in rat brain. Pol J Pharmacol 2013; 55: 1037-43.

27. Yayla N. Ratlarda Parasetamolle İndüklenen Akut Karaciğer Toksisitesi Üzerine Nigella sativa L. Etanol Ekstresinin Etkilerinin Araştırılması, (Yüksek Lisans Tezi), Yasin Bayır, Yayınlanmış Tez, Erzurum, 2014.

28. Sayed-Ahmed MM, Nagi MN. Thymoquinone suplementation prevents the development of gentamicin-induced acute renal toxicity in rats. Clin Exp Pharmacol Physol 2007;34 (5), 399-05.

29. Abdelmeguid NE, et al. Effects of Nigella sativa and thymoquinone on biochemical and subcellular changes in pancreatic $\beta$-cells of streptozotocin-induced diabetic rats. J Diabetes 2010;2(4):256-66. 